22. Theory of Literature: a textbook for students of philological faculties of universities: in 2 volumes [Teoriya literaturyi: uchebnoe posobie dlya studentov filologicheskih fakultetov vuzov: v 2 tomah]. Edited by N.D. Tamarchenko. Volume 1. Moscow: Academy, 2007. 512 p.

23. Khalizev, Ye.V. (2002). Theory of Literature: A Textbook [Teoriya literatury: Uchebnik]. Vysshaya shkola, Moskow. 438 p.

24. Khodasevich, V.F. (2008). Necropolis [Nekropolis]. Azbuka-klassika, St. Petersburg. 320 p.

25. Tsvetaeva, M.I. (1989). Art in the light of conscience [Iskusstvo pri svete sovesti]. Azbuka, St. Petersburg. 347 p.

26. Chukovskaya, L.K. (1989). Notes on Anna Akhmatova. Book 1 [Zapiski ob Anne Akhmatovoy. Kniga 1]. Kniga, Moskow. 272 p.

27. Shvets, N. (2003). Pushkinian as an artistic tradition in the perception of the "Silver Age" and in the views of N. Medtner, Musicology: a collection of articles. Art studies and cultural studies [Kyyivs'ke muzykoznavstvo, Mystetstvoznavstvo i kul'turolohiya]. Kiev, R. Glier Kyiv Institute of music. p. 143-151.

УДК 78.071.1(477):82-1(470)

ORCID: 0000-0002-7463-8467

\begin{abstract}
Наталія Тугушева,
аспірант кафедри історії світової музики Начіональної музичної академї Украӥни ім. П. І. Чайковського вул. Архітектора Городецького, 1-3/11, Київ, 02000, Украӥна

Nataliya Tugusheva, Postgraduate at the Department of History of World Music, Ukrainian National Tchaikovsky academy of music, 1-3/11 Architect Gorodetsky St., Kyiv 02000, Ukraine
\end{abstract}

\title{
ВІРШ О. ПУШКІНА «Я ВОЗМУЖАЛ СРЕДИ ПЕЧАЛЬНЫХ БУРЬ» У ДВОХ МУЗИЧНИХ ПРОЧИТАННЯХ УКРАЇНСЬКИХ КОМПОЗИТОРІВ - С. СТАНКОВИЧА ТА Ю. ІЩЕНКА
}

У статті розглянута II частина камерної симфонії №4 «Пам’яті Поета» $Є$. Станковича, а також романс для голосу з фортепіано Ю. Іщенка. Центральним для Станковича став образ «небесної лазурі», що вплинуло на загальний просвітлений та умиротворений характер музики. Іщенко акцентує внутрішню напругу, сумніви та тривогу як домінантні образи. Об'єднуючим елементом музичних прочитань виступила гармонія, якій обидва композитори відвели першочергову роль.

Ключові слова: Станкович, камерна симфонія №4, Іщенко, образ лазурі, роль гармонії.

A. Pushkin's poem «I matured amidst the sad storms» in two music interpretations of Ukrainian composers - E. Stankovych and Yu. Ishchenko. This article considers the second part of the chamber symphony №4 «In Poet’s memory» by E. Stankovych and a romance for voice and piano by 
Yu. Ishchenko. Image of «azure sky» becomes the central one for Stankovych, which affected common lighted and pacified music's character. Ishchenko makes accent on inner tension, doubts and anxiety as a dominant spheres. Common to both musical interpretations became the harmony's big role.

Key words: Stankovych, chamber symphony №4, Ishchenko, azure’s character, harmony's role.

Стихотворение А. Пушкина «Я возмужал среди печальных бурь» в двух музыкальных прочтениям украинских композиторов Е. Станковича и Ю. Ищенко. В статье рассмотрена II часть камерной симфонии №4 «Памяти поэта» Е. Станковича, а также романс для голоса с фортепиано Ю. Ищенко. Центральным для Станковича стал образ «небесной лазури», что повлияло на общий просветленный и умиротворенный характер музыки. Ищенко акцентирует внутреннее напряжение, сомнения, тревогу в качестве доминантных образов. Объединяющим элементом музыкальных прочтений становится гармония, которой оба композитора уделили первостепенную роль.

Ключевые слова: Станкович, камерная симфония №4, Ищенко, образ лазури, роль гармонии.

Я возмужал среди печальных бурь, И дней моих поток, так долго мутный,

Теперь утих дремотою минутной И отразил небесную лазурь.

Надолго ли?.. а кажется, прошли Дни мрачных бурь, дни горьких искушений...

Цей лаконічний вірш Олександра Пушкіна, написаний у 1834 році, схожий скоріше на ескіз до свого більш розгорнутого варіанту. Можливо, саме цим викликано відсутність його аналізу у літературі. Але незважаючи на удавану недовершеність, зміст вірша цілком зрозумілий, а головну ідею виражено якраз через ефект ескізності, незавершеності. Актуальність та новизна даної статті визначаються саме зверненням до поетичного та музичного текстів, які поки що не привернули достатньої уваги дослідників, а також тим, що розглянуті музичні твори належать видатним українським композиторам-сучасникам - С. Станковичу та Ю. Іщенку. Метою роботи стало виявлення загальних та індивідуальних рис у двох музичних прочитаннях пушкінського вірша.

Вірш написаний п’ятистопним ямбом з використанням кільцевого типу рими і чергуванням чоловічих та жіночих завершень. Всі дієслова використано у минулому часі (возмужал, утих, отразил, прошли). Така ретроспективність вносить як ностальгічну ноту, так і відтінок деякої підсумковості. 
Можна прослідкувати всі три часові виміри у творі. Так, перші два рядки відображають минулі «бурі», два наступні говорять про теперішній острівець спокою, а два заключні, що окремо виділені, ставлять питання до невідомого майбутнього. Показово, що найкоротшим $є$ теперішній час, це підкреслено виразом «дремотою минутной», де обидва слова асоціативно пов'язуються із чимось нетривалим (дрімота - стан поверхневого, неглибокого сну, «минутной» - пряма вказівка на швидкоплинність моменту). Посилює контраст ще й оточення цього короткого теперішнього часу словами «долго» - це «поток, так долго мутный», а в майбутньому -питання «Надолго ли?».

У вірші можна виділити дві пари семантичних опозицій: «буря»«лазурь» і «мутный» - «небесный». Переважають образи 3 негативними конотаціями: печальні і похмурі бурі, мутний потік, гіркі спокуси. Всі вони розосереджені у вірші, тому викликають загальний похмурий настрій, тоді як єдиний світлий образ небесної лазурі виникає лише один раз, немов один сонячний промінь, що пробився крізь сірі хмари.

Ключова роль в ефекті незавершеності твору належить двом останнім рядкам. Вони не мають рими, оскільки наступні рядки в тексті відсутні. Через те, що продовження немає, у монологічній мові виникає ефект запитання. Він посилюється завдяки двом підряд фразам, що виражають невпевненість: питанню «Надолго ли?» і прислівнику «кажется». В обох цих фразах Пушкін використовує потужний засіб пунктуації - багатокрапку, що лишає за собою шлейф невизначеності.

До нас дійшли ще як мінімум два робочі варіанти цього вірша.

\section{Перший варіант}

Я возмужал средь бурных искушений

И дней моих взволнованный ручей

Теперь утихнул. Мира ясный Гений. . .

\section{Другий варіант}

Я возмужал среди печальных бурь

И дней моих поток так долго мутный

Теперь утих - и ясная лазурь... У першому варіанті зміни здаються більш динамічними, енергійними та світлими у порівнянні із кінцевим варіантом. Так, «взволнованный ручей» життя асоціюється із постійним оновленням та чистотою, тоді як у «мутному потоці» вгадується хаотичний тип руху та змішення різнопорядкових елементів. У другому варіанті Пушкін впритул наблизився до кінцевого. Але перехресний тип рими зближує позиції «бурь-лазурь», а завдяки кільцевій римі автор ніби збільшує часовий проміжок між подіями минулого і теперішнього. 
Станкович, здавалося б, розставляє у вірші зовсім інші акценти. Стислий, затуманений сумнівами та ностальгією вірш Пушкіна композитор трактує як неквапливий, просвітлений та умиротворений. Головним джерелом такого прочитання стає образ небесної лазурі, який музично втілено у відокремленому оркестровому епізоді. Цей найменш тривалий світлий момент вірша розгорнуто у музиці максимально довго, він визначає характер усієї другої частини симфонії Станковича. Композитор просто поглянув на вірш крізь іншу лінзу, у якій один світлий мазок став для нього більш яскравим та виразним, аніж превалюючі темні фарби. Він побачив весь пушкінський вірш крізь призму одного образу - ясної небесної лазурі.

Відштовхнувся Станкович, мабуть, від початкової фрази, змістивши акцент 3 «печальных бурь» на вираз «Я возмужал», що несе в собі асоціації із життєвою мудрістю, накопиченим досвідом, спокійним прийняттям всіх негараздів. Саме тому було обрано комплекс виразових засобів, які максимально спрямовані на заспокоєння. Це дуже повільний темп (molto lento), динаміка pp, прозора та ніби невагома фактура, протягнутий декілька тактів до-мажорний тризвук, кришталеві звуки фортепіано у високому регістрі.

Як наслідок зміщення кута зору, у вокальній партії з’явилися постійні цезури, що посилюють спокійний, неквапливий, розповідний тон висловлювання. Вони виникають не тільки між окремими фразами (тобто, рядками вірша), але i всередині фраз, подовжуючи та акцентуючи окремі слова, що у Пушкіна метрично не виділені. Так, Станкович протягує звучання слів «Я возмужал», «долго», «лазурь», що в нотному тексті оформлено через фермати.

У Пушкіна лише два заключні рядки можна вважати запитальними, всі попередні є стверджувальними і за своєю структурою, і за змістом. Тому у Станковича вокальні інтонації мають здебільшого низхідні завершення, що надає їм м'якості. Саме така вокальна партія, де кожна фраза завершується низхідним ходом та протягнутим довгим звуком, концентрує в собі та підкреслює загальний споглядальний та навіть ствердний тон висловлювання.

Проте внутрішній драматизм та експресія образів вірша («печальные бури», «мутный поток», «мрачные бури», «горькие искушения») також присутні у зовні врівноваженій вокальній партії. Композитор, немов художник, будує іiі крупними мазками - вже перша інтонація охоплює діапазон нони. Для акцентування окремих слів Станкович використовує стрибки на широкі інтервали (квінту, сексту, септиму), часто дублюючи при цьому вокальну партію інструментами оркестру. 
Найбільше внутрішнього руху виникає у відокремленому оркестровому епізоді, що покликаний відобразити «небесную лазурь» інструментальними засобами. Він складається лише із семи тактів та їх повторення на вищому динамічному рівні. Але поліфонічно насичена фактура, одночасні ритмічні накладення та дзеркальні відображення мелодичних фраз створюють тривалий ефект активного перетікання, постійного оновлення.

Єдиний контраст виникає перед запитанням «Надолго ли?», що виражає сумніви і тривогу. Після просвітленого та насиченого внутрішнім життям оркестрового епізоду всі інструменти сходяться в один різкий дисонанс, що порушує загальний спокій. Сама вокальна інтонація на словах «Надолго ли?..» має яскраво виражену романсову жанрову природу. Подібні фрази з висхідною інтонацією малої сексти а далі низхідним рухом стали уособленням традиційних елегійних зітхань, жаліб, а також риторичних запитань. Композитор ритмічно виділяе у цій елегійній формулі саме початковий висхідний стрибок, підкреслюючи знак питання («Надолго ли?..»), а далі низхідне завершення фрази - знак непевності (багатокрапка у Пушкіна).

Важливу роль у створенні загального просвітленого колориту відіграє гармонічна мова Станковича з переважанням мажорних звучань. 3 одного боку іiі можна вважати функціональною, оскільки рух гармонії легко прослідковується за басовою лінією. Проте оркестровий епізод і наступне завершення мислиться лінійно, тому що музична тканина складається тут з чотирьох оркестрових пластів окрім власне мелодичної лінії. Всі ці горизонтальні пласти утворюють квазі-кластерне звучання, посилене поєднанням різних типів фактури (тремоло, звуки піцикато, пасажі). Якщо спробувати зупинити цей рух в одній точці, то вертикаль кожного з оркестрових пластів складатиме приблизно одні й ті ж самі звуки, тільки у різних регістрах ${ }^{1}-$ звідси виникає відчуття стійкості, навіть діатонічності епізоду.

Після просвітленого оркестрового епізоду м'яка гармонія ніби повертається до тривожної реальності, сповненої сумнівів («Надолго ли?»): переважають вертикальні кластерні співзвуччя мінорного нахилу. А пушкінська багатокрапка та невизначеність втілюються відсутністю гармонічних кадансів і взагалі будь-якої ладо-тональної опори.

Своєрідність рішення Станковича особливо помітна у порівнянні 3 іншим музичним прочитанням цього пушкінського вірша - романсом

\footnotetext{
${ }^{1}$ Наприклад, у другому такті оркестрового епізоду, коли і в басу, і в мелодії голоси зупинилися на половинній тривалості, маємо такі вертикалі: у низьких струнних - e-gh-c-d, у тремолюючих альтів та скрипок - e-g-a-h-c-d, у скрипок піцикато - e-b-c-d-es, у фортепіано - e-f-g-a-h-c, а в мелодії звук h.
} 
Ю. Іщенка для голосу та фортепіано. Його було написано у тому ж році, що і камерну симфонію Станковича (1987). На відміну від Станковича, весь романс Ю. Іщенка сповнено внутрішньою напругою, сумнівами, тривогою. А образ небесної лазурі втілено лише короткотривалим просвітленням.

Важливим засобом створення переважно похмурого настрою стає для Іщенка гармонія, яка формує ланцюжки гармонічних послідовностей по звукам 3мVII7. Таким чином, у лінії басового супроводу виникають малотерцеві співвідношення тризвуків, що ніби розфарбовуються відтінками далеких тональностей (f-D-h-gis-f; es-c-A-fis-es). Іноді при повторенні ланцюжка мінорні тризвуки замінюються на однойменні мажорні, що вносить ефект світло-тіні: яскравого й одразу ж тьмяного відтінку. Одномоментним «виринанням» із гущі мінорних фарб стає епізод з «небесною лазур'ю» - тут композитор єдиний раз використовує ланцюжок із п'яти підряд мажорних тризвуків - C-A-Fis-Es-A.

Будова вокальної партії створює враження обмеженого простору, замкненого руху по колу, оскільки мелодія має тісний діапазон та хвилеподібну структуру, часто повертаючись до початкового звуку фрази.

Головною відмінністю двох музичних творів стає вирішення фіналу вірша. Якщо у Станковича музика втілює пушкінську багатокрапку та відкритість фіналу, то Іщенко робить навпаки. Повторюючи вкінці запитання «Надолго ли?» і потім початковий рядок «Я возмужал среди печальных бурь», він замикає весь попередній розвиток і повертає його до початкової точки. Можливо, таким чином композитор намагався втілити безвихідь: печальні бурі та гіркі спокуси неминуче повернуться...

Загальним для обох музичних інтерпретацій став прийом повного динамічного та ладо-тонального контрасту перед тривожним запитанням «Надолго ли?». Але в романсі Іщенка кульмінацію пов'язано з посиленим повторенням цього питання, яке звучить вже не стільки невпевнено, скільки пронизливо, як болісний вигук. Також об’єднує музичні прочитання роль гармонії як своєрідного образного камертону.

\section{1. Мазель Л. А. Анализ музыкальных произведений. М.: Музыка, 1967. 752 с.}

\section{References}

1. Mazel, L. A. (1967). Analysis of musical works [Analiz muzyikalnyih proizvedeniy]. Moscow, Muzyika. 752 p. 